Table 1. Plasmin-leveid in the INFANT Rat and KITten domPARED WITH THE ADULT RAT AND CAT (EXPRESSED AS PERCENTAGE

\begin{tabular}{|c|c|c|c|c|c|c|}
\hline \multirow[b]{3}{*}{$\begin{array}{c}\text { Age } \\
\text { (days) }\end{array}$} & \multicolumn{6}{|c|}{ LYSIS OF FIBRIN CLOT AFTER 2 HR.) } \\
\hline & & Rat & & & Cat & \\
\hline & $\begin{array}{c}\text { plasmin } \\
\text { level } \\
\text { (per cent) }\end{array}$ & $\begin{array}{l}\text { No. of } \\
\text { observat- } \\
\text { tions }\end{array}$ & S.D. & $\begin{array}{l}\text { Mean } \\
\text { plasmin } \\
\text { level } \\
\text { (per cent) }\end{array}$ & $\begin{array}{l}\text { No. of } \\
\text { observa- } \\
\text { tions }\end{array}$ & S.D. \\
\hline 1 & $11 \cdot 3$ & 8 & 1 . & $4 \cdot$ & 4 & $3 \cdot 0$ \\
\hline 3 & $5 \cdot 2$ & 4 & 12 . & 1.7. & 3 & 1.8 \\
\hline & 17. & 3 & $4 \cdot 1$ & $50 \cdot 6$ & 3 & $9 \cdot 2$ \\
\hline 5 & $52 \cdot 3$ & 3 & $4 \cdot 5$ & $37 \cdot 5$ & 4 & $6 \cdot 0$ \\
\hline adult & $61 \cdot 5$ & $i$ & $11 \cdot 7$ & $46 \cdot 2$ & 4 & $6 \cdot 2$ \\
\hline
\end{tabular}

Table 1 shows that low plasmin-levels are present in early post-natal life in both the rat and the cat. In the cat, plasma fibrinolytic activity comparable with that of the adult is attained in 4 days, while this does not occur in the rat until the age of 5 days. The difference in time at which the enzyme appears in the two animals may be attributed to the lessmature state of the rat at the time of birth compared with the kitten. These findings suggest that in these two animals plasmin belongs to the group of enzymes which appear to be inactive until after birth.

At the present time we are conducting a more extensive investigation of fibrinolytic activity in the blood of premature and full-term laboratory animals and human infants.

B. G. R. Nevrlute

R. G. SPECTOR

Pædiatric Research Unit,

Guy's Hospital Medical School, Guy's Hospital,

London, S.E.1.

${ }^{1}$ Fleming, W. H., Srakacs, J. E., Hartney, T. C., King, E. R., Lancet, il, 1010 (1960)

${ }^{2}$ Gitlin, D., and Craig, J. M., Pediatrics, 17, 64 (1956).

- Lieberman, J., New Engtand J. Med., 265, 363 (1961).

4 Smith, C. A., J. Pediat., 56, 605 (1960).

'Andrews, W. H. H., Britton, H. G., and Nixon, D. A., Nature, 191, $1307(1061)$

'Richter, D., Brit. Med. Bull., 17, 118 (1961).

- Biggs, R., and Maefarlane, R. G., in Human Blood Coagulation and its Disorders, second ed., 412 (Oxford, 1957).

\section{Effects of Stilbcestrol and Thiouracil on the Electrocardiograms of the Sheep}

THE use of stilboestrol and thiouracil in enhancing the fattening efficiency of livestock has emphasized eapsule of 'Adoxiline' (Glaxo) was given as vitamin A and D supplement once a week. The first group served as control, in the second $20 \mathrm{mgm}$. stilbostrol (M. and B.) in pellet form was implanted under the skin, and $1 \mathrm{gm}$. of thiouracil (B.D.H.) per $100 \mathrm{lb}$. live weight was supplemented daily in the third group. For electrocardiographic recording, the method described by Mullick ${ }^{1}$ was followed.

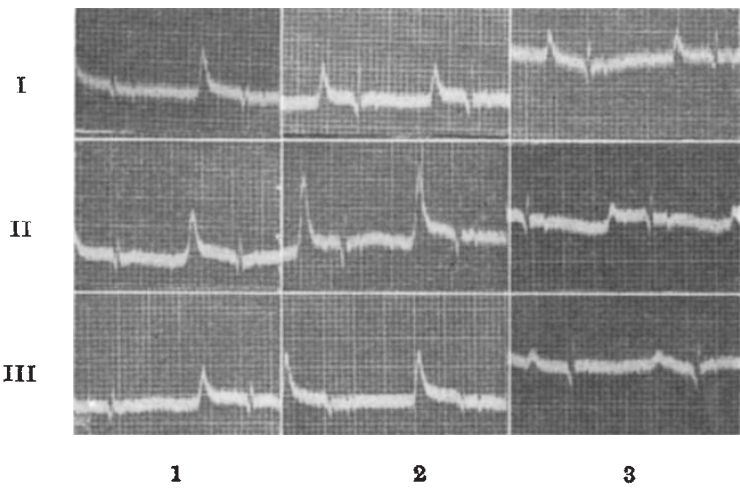

Fig. 1. 1, Control group; 2, stilboestrol group; 3, thiouracil group

Table 1 and Fig. 1 show the summary of the electrocardiographic records.

Normal electrocardiogram: all the $P$ waves were upright. Slight variation was recorded in the form of $Q R S$. In all the tracings, $Q$ and $R$ waves were prominent, whereas very few $S$ waves were noted. All $T$ waves were inverted.

Electrocardiogram following stilboestrol implantation: The heart-rate was slow and the interval and potential figures were higher. The significant change in the potential of the $T$ waves indicated greater force of the heart output in each beat, whereas in other waves the changes were not appreciable. The absence of $S$ waves was conspicuous.

Electrocardiogram following thiouracil feeding: The same trend of change in the heart-rate, intervals and potentials was noted as before but to a smaller extent.

It appears that the pharmacological action of these drugs may affect the normal physiological function

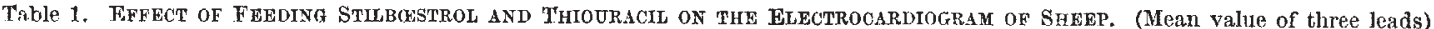

\begin{tabular}{|c|c|c|c|c|c|c|c|c|c|}
\hline \multirow[b]{2}{*}{ Group } & \multirow{2}{*}{$\begin{array}{c}\text { Heart } \\
\text { rate } \\
\text { (beats/ } \\
\text { min.) }\end{array}$} & \multicolumn{3}{|c|}{ Intervals (sec.) } & \multicolumn{5}{|c|}{ Potentials ( $\mathrm{mV}$.) } \\
\hline & & $P R$ & QRS & $Q T$ & $P$ & $Q$ & $R$ & $s *$ & $T$ \\
\hline $\begin{array}{rr}\text { Control } & M^{1} \\
\pm S . D . \\
\text { Stilboestrol } M \\
\pm S . D \\
\text { Thiouracil } M \\
\pm S . D .\end{array}$ & $\begin{array}{r}78 \cdot 0 \\
8 \cdot 5 \\
75 \cdot 0 \\
11 \cdot 2 \\
65 \cdot 0 \\
12 \cdot 8\end{array}$ & $\begin{array}{l}0 \cdot 124 \\
0 \cdot 001 \\
0 \cdot 127 \\
0 \cdot 001 \\
0 \cdot 134 \\
0 \cdot 001\end{array}$ & $\begin{array}{l}0.057 \\
0.020 \\
0.059 \\
0.021 \\
0.062 \\
0.023\end{array}$ & $\begin{array}{l}0 \cdot 317 \\
0.034 \\
0 \cdot 322 \\
0 \cdot 036 \\
0 \cdot 335 \\
0 \cdot 038\end{array}$ & $\begin{array}{l}0 \cdot 100 \\
0 \cdot 030 \\
0 \cdot 110 \\
0 \cdot 030 \\
0 \cdot 075 \\
0 \cdot 030\end{array}$ & $\begin{array}{r}-0 \cdot 330 \\
0 \cdot 110 \\
-0 \cdot 320 \\
0 \cdot 080 \\
-0 \cdot 400 \\
0 \cdot 100\end{array}$ & $\begin{array}{l}0 \cdot 220 \\
0 \cdot 120 \\
0 \cdot 260 \\
0 \cdot 140 \\
0 \cdot 190 \\
0 \cdot 120\end{array}$ & $\begin{array}{c}-0.100 \\
= \\
=\end{array}$ & $\begin{array}{r}-0.290 \\
0.100 \\
-0.710 \\
0.290 \\
-0.660 \\
0.220\end{array}$ \\
\hline
\end{tabular}

* Figures are not sufficient.

$1, M$ represents the average of four sheep with \pm S.D., standard deviation.

the importance of undertaking the present investigation on the physiological effects of these drugs on sheep.

Electrocardiographic tracings were recorded fortnightly for 6 months on 12 adult sheep, divided into three identical groups of four each. They were fed daily on a ration consisting of groundnut cake ( $4 \mathrm{oz}$.$) ,$ barley (12 oz.), salt $(1 \mathrm{oz}$.$) and oat hay ad lib. A$ of the cardiac cycle, and hence requires consideration in their administration.

\section{N. MuLlick}

V. N. Murty

Animal Nutrition Division,

Indian Veterinary Research Institute, Izatnagar.

${ }^{1}$ Mullick, D. N., Brit. Vet. J., 115, $416(1959)$. 